\title{
Understanding and Selecting Sharia or Conventional Financing Among Small Entrepreneurs, in Pasuruan Regency Devout of Islamic Culture (Phenomenology Studies)
}

\section{Hartutik}

Islamic Economics Department, University of Muhammadiyah Jakarta

\section{Abstract}

Purpose: Knowing the understanding and interest of small-scale business actors about Islamic finance in Pasuruan Regency, which is culturally devout Design/Methodology/Approach: Phenomenology method is used to find the meaning and nature of the experience of small entrepreneurs when using Islamic or conventional financing, as well as how the small entrepreneur responds to Islamic financing.

Findings: The results of this study indicate that the Satrya Emas program has not been understood by most informants and has notyet specifically synergized with Islamic

Corresponding Author:

Hartutik

hartutik026@gmail.com

Received: 16 September 2019 Accepted: 28 September 2019 Published: 31 October 2019

Publishing services provided by Knowledge E

(c) Hartutik. This article is distributed under the terms of the Creative Commons

Attribution License, which permits unrestricted use and redistribution provided that the original author and source are credited.

Selection and Peer-review under the responsibility of the ICEMA Conference Committee.
Financial Institutions. Most of the informants did notunderstand various sharia financing contracts and products, in addition, they did not own the right understanding on whether or not bank interest is halal and haram due to their lack of knowledge and information. Financial institutions were chosen because some informants believed the Al-Quran and Hadist laterally. Other reasons are understanding that bank interest is halal paid, haram when consumed. Moreover, there was a facility of jemput bola, meaning that banks initiate to approach clients to provide loan, and also the ease, flexibility and kinship in dealing with bad debt. It is not a priority for most informants to utilize sharia or conventional financing. Almost all informants did not own good and correct financial records, so they assessed the progress of their business in accordance with their respective perceptions. Special supports from the PasuruanRegency government are required, and the collaboration of various parties, amonggovernment, religious leaders, educational institutions, Islamic financial institutions, and non-governmental organizations. Thus, theyall jointly synergize topromote sharia financing in the area of Pasuruan Regency

Originality/value:This research collaborates the study of the experiences of small-scale entrepreneurs as subjects, finance institutions, religious teachers and the government, so that the results of this study can be a reference for regulators and local governments to make policies capable of accommodating different understanding groups so that Islamic finance is able to ground in areas that have a devout Islamic culture.

Keywords: Sharia Financing, Phenomenology, Small Business 


\section{Introduction}

This study examines how the understanding and interest of small-scale business actors towards Islamic finance in Pasuruan Regency is culturally Islamic. Pasuruan Regency is called santri city, has a devout Islamic culture, $97 \%$ of its citizens are Muslim (East Java Ministry of Religion, 2015), has 321 Islamic boarding schools (Radar Bromo, 2017), and holds compulsory learning diniyah to explore, understand and practice Islamic religious sciences properly and correctly (Perbup Pasuruan, No. 21 of 2016). Ideally, Islamic financing is a solution to the problem of business capital needs, especially small businesses ( J. Green, Christopher et al, 2006). In fact, not all citizens interact with Islamic Financial Institutions and choose Islamic finance as a solution for business capital needs. The fact is that the number of conventional BPR institutions is $85.71 \%$, larger than Sharia BPR which is only $14.29 \%$. Fund distribution was also still dominated by Conventional Rural Banks amounting to $57 \%$ exceeding the disbursement made by Sharia Rural Banks by $43 \%$, third party Sharia Rural Banks only $13 \%$, far below Conventional Rural Banks which reached $87 \%$ (BI Publications, 2015). The reality of the development of Islamic Financial Institutions and Islamic financing is still far from expectations, not all Muslims have interacted with Islamic Financial Institutions and not all Muslims choose sharia financing to overcome the funding needs solution

This study uses Husserl's transcendental phenomenology study. According to Husserl in Engkus (2009), with phenomenology we can learn forms of experience from the point of view of those who experience them directly, as if we experience them ourselves, but also look for the reality behind the phenomenon. So in practice, phenomenology tends to use methods of observation, in-depth interviews (qualitative), and document analysis with hermeneutic methods (Kuswarno: 2013; 36). Phenomenology basically tries to understand how a person experiences and gives meaning to an experience. Phenomenology aims to know the world from the point of view of the person who experiences it directly, or is related to the nature of the human experience, and the meaning attached to it. In this study because of phenomenology-based, then what is examined here is not the Financial Institution, Business Unit, Business Performance, or regulation, because all of them are not individuals who feel an experience in financing. The focus of this research is personal / individual business actors who are utilizing funding from financial institutions.. 


\section{Theoritical Framework}

\subsection{The Problem of MSME Financing}

Operationally, MSMEs are difficult to access information, such as difficulties in marketing, difficulties in obtaining financing due to the low trust of various financial institutions due to the large number of MSMEs that are not legal entities, have no financial reports, have no collateral, are unable to make comprehensive credit proposals (not bankable) The results of Haikal and Ismaeni's (2008) research in BI Academic Studies (2011: 24), to have bankable status there are at least six aspects that must be addressed, namely the problem of Entrepreneurship, Products, Production / Operations, Marketing, Finance, Legal. Following is a summary of the potential MSME processes to become Bankable. Ram Consultancy (2005) in BI Academic Study (2011), stated that the obstacles to the development of MSMEs in various countries that were most commonly encountered were the problem of funding or financial access. In general, the main causes of funding problems can be seen in terms of supply and demand. From the supply side, a common obstacle was crowding out in the private sector, the implementation of government funding programs that were less than optimal, the complex credit provision process, the inconsistent definition of MSMEs, and the over-banked situation. On the demand side, the main obstacle encountered was the lack of documentation regarding historical data on MSMEs and the limited assets that could be used as collateral when applying for loans

\subsection{Sharia MSMEs Welfare Indicators and Analysis}

In terms of welfare, Islamic Economics has a different view from conventional economics. In Islam it has been mentioned in the Koran, that Allah has guaranteed the welfare of His servants and all living beings (QS Hud; 6) which means "And there is no animal in the earth but Allah gives its sustenance". Nevertheless, Allah explained that humans or all beings must make an effort to get their welfare, as it is in (Surah Ar Ra'd: 11) which means "Verily Allah does not change the state of a people so that they change the conditions that are in themselves " Prosperity does not come by itself, welfare must be sought and championed. Welfare is not only measured materially only from the amount of income and consumption, but more than that, welfare is a combination of material and spiritual balance (welfare that is falah). Falah Welfare, is a real success, namely happiness and prosperity in the world and the hereafter. In the 2015-2016 Indonesian Sharia Banking Roadmap, it is stated that in order to achieve the prosperity of the Falah, in the economy 
must have a strong foundation in the form of Faith, Sharia, Morals and Ukhuwah. Like a foundation building providing basic strength for the establishment of a pillar in the form of justice, balance and benefit. The following is a description of the foundations, pillars and welfare of Falah (Sharia Banking Roadmap, 2015-2019)

\subsection{The principle of empowering MSMEs}

The principle of empowering Micro, Small and Medium Enterprises according to Law No. 20 of 2008: a) The growth, independence, togetherness and entrepreneurship of Micro, Small and Medium Enterprises to work on their own initiative; b) The realization of a transparent, accountable and just public policy; c) Development of regional potentialbased and market-oriented businesses in accordance with the competencies of Micro, Small and Medium Enterprises; d) Increasing the competitiveness of Micro, Small and Medium Enterprises; e) Implementation of integrated planning, implementation and control

\subsection{Sharia Financing}

The implementation of Islamic financing activities must comply with the principles of Justice ('adl), Keseimbangan (Tawazun), Kemaslahatan (maslahah), and Universalism (Alamiyah), and not contain Gharar, Maysir, Riba, Zhulm, Risywah, and Haram objects. The Law of the Republic of Indonesia No. 21 of 2008 concerning Sharia Banking states that Financing is the provision of funds or equivalent claims in the form of: a) Profit sharing transactions in the form of mudharabah and musyarakah: b) Leasing transactions in the form of ijarah or rent buy in the form of ijarah muntahiyah bittamlik;; c) Sale and purchase transactions in the form of murabahah, greetings, istishna '; d) Transaction of borrowing and borrowing in the form of qardh receivables; and; e) Rental transactions lease services in the form of ijarah for multi-service transactions. In Islamic finance, the contract becomes a necessity in the transaction, Law No. 21 of 2008, stating the definition of a contract is a written agreement between a Sharia Bank or UUS and another party that contains the rights and obligations of each party in accordance with the Sharia Principles. 


\subsection{Bank Interest or Usury}

Among the signs of justice is the prohibition of having mercy with usury. Allah and Rasul, openly fight the perpetrators of usury, as mentioned in Surah Al-Baqarah: 279 "O ye who believe, fear Allah and leave the rest of usury (which has not been collected) if you are believers. if you do not work (leaving the remaining usury) then know that Allah and His Messenger will fight you, and if you repent (from taking usury) then to you the principal of your treasure you do not persecute nor are persecuted "the Prophet, judge usury included in" seven mubiqat "that is destroying individuals and society, the world and the hereafter. The Prophet cursed eaters and usurers, writers and two witnesses by saying, "they are all the same" in committing sin, despite the different levels of sin. HR Ahmad and Muslim from Jabir (Qardhawi, 2016: 167)

\subsection{Thought in Islam}

Current Islamic Thought (Contemporary), that the Revivalism movement (ijtihad) in the present, there are two developing, namely the Neo-Revivalism Movement, its thinking; reject the westernization of Muslims, Defend the adequacy of Islam as a view of life and reject all forms of interpretation of the Koran and Sunnah. Modernism movement, his thinking; Exploring the principles that are relevant to the Koran and the Sunnah of the Prophet. Formulating things based on these principles. Criticizing the failure of the early fuqaha in understanding the underlying unity. socio-historical background, Al-Quran is a response to historical situations which include moral, religious and social teachings in answering the problems faced. (Hadi, 2009; 296)

\section{Method}

In accordance with the focus of the research, the type of transcendental phenomenology was chosen in which researchers tried to examine a phenomenon by ignoring prejudice about the phenomenon. In accordance with what was conveyed by Moustakas (1994) in Cresweel $(2015 ; 110)$ that transcendental phenomenology is less focused on the interpretation of researchers, but rather focuses on the description of the experiences of the participants. So in transcendental phenomenology, researchers get rid of their experience to obtain fresh or new perspectives on the phenomenon being studied. 


\subsection{Research Site}

Researchers are interested in using Pasuruan as a place of research, because Pasuruan is an area that has a majority Muslim population with a thick Islamic culture. As a santri city; Pasuruan Regency also has a pretty good economic potential for its development, because the location of the region is very strategic which connects big cities like Surabaya, Malang, Jember, and Bali; This research was conducted in the area of Pasuruan regency, focusing on 6 (six) development areas / sub-districts, namely Grati, Gondangwetan, Purwosari, Bangil, Kejayan and Pandaan Districts, these six places are the service places of the Satrya Emas Program which is a regional government program to empower MSMEs in the District Pasuruan thus it is expected that the small-scale business actors in several sub-districts have obtained the knowledge of both the theory and practice of how to do financing to both conventional and sharia financial institutions.

\section{Research Instruments}

In this study the main instrument is the researcher himself. The collected data is subjective, researchers are required to be able to dig data based on what is said, felt, and done by informants or data sources. Therefore in qualitative research "the researcher is the key instrument" (Sugiyono, 2016; 373).

\section{Data Collection Process}

Data collection is the process of gathering information to answer research questions that arise. Following are the steps of data collection according to Creswell (2016; 207), 1) Determining the place / individual, here relating to the interest of researchers in the Pasuruan Kabuaten region, the majority of which are Muslim and devoutly Muslim. 2) Obtain access and build relationships. With preparation for access and flexible relationships, it is hoped that the interview process is more comfortable and more expressive so that the results of the research present empirical truths that are closer to reality or valid. 3) Purposeful sampling, the researcher chooses the place or community to be studied. To support the results of good and relevant research, researchers take groups of people who are considered able to provide the best and most complete information because in addition to the sub-districts including the area, population and type of business is complex; 4) Collecting Data, In the study of transcendental phenomenology, researchers want to explore the awareness of informants, for this 
reason an analytical technique is used in which the stages start from Noema-NoesisEpoche (bracketing) - Intentional analysis, Eidetic Reduction to the saturation point..; 5) Recording Information, to collect information in addition to storing the results of interviews in a tape recorder, the researcher also made transcripts of the interview. To facilitate mapping of Noema-Epoche-Noesis-Intentional analysis, researchers make a kind of working paper. 6) Solving field problems, the reality in the field is not as smooth and smooth as expected, for this reason researchers need to anticipate inadequate data, so if the data is inadequate, researchers review and consult the promoters and co-promoters. 7) Saving data, in storing data on qualitative research, Davidson (1996) in Creswell (2016) recommends always making coffee or backups for computer files, using high-quality tape to record information during interviews

\subsection{Validity and Reliability Research}

Validity and Reliability in research is related to the concept of measurement. Reliability refers to the extent to which a measurement produces the same or consistent answer, while validity refers to the extent to which a measurement produces truth or matches reality. Validity and reliability in this qualitative research is that data analysis and data acquisition processes are presented in detail and the findings of the study are expected to be very relevant to the values that exist in the community (Kamayanti 2016; 57-59).

\section{Result}

Research using subjects of Small Entrepreneurs in Pasuruan Regency and the object of research in the form of small-scale entrepreneurs' understanding of the selection of financing sources, is carried out through a process of typing the level of education and activeness of subjects in community activities. the following:

TABLE 1: Typification of Research Subjects.

\begin{tabular}{l|l|l}
\multicolumn{1}{c}{ Level of education } & \multicolumn{2}{c}{ Community Economic Activities } \\
\cline { 2 - 3 } & Active (1) & Not Active (2) \\
A (S1) & Mrs. Dewi & Mr. Toni \\
\hline B (D3) & Mr. Irwanto & Mr. Udin, Mr. Abil, Mr. Saiin \\
C (SMA) & Mr. Ridwan, Mrs Susi, Mrs Sri & Mrs Masfiah \\
D (SD,SMP) & Mrs Supiah & \\
Source: Primary & Data Processed
\end{tabular}


able 2, the typification of research subjects can be described as follows

A1 Is a code of research subjects with an $\mathrm{S} 1$ level of education and active in community economic activities. Mrs. Dewi is a craft craft producer in her neighborhood, as well as being active as a member of the CSR Aqua Pandaan management in the field of Economics

A2 Is a code of research subjects with an undergraduate education level and is not active in community economic activities

B1 Is the code of research subjects with a level of D3 education and active in community economic activities, namely Disnaker partners in providing mentoring for mushroom cultivation in the Pasuruan district

C1 Is the code of research subjects with high school education level and active in community economic activities, namely Haji Ridwan partner Disperindag and as chairman of the HIAS association, besides Susi Krisna as FOCUS coordinator as well as secretary 2 HIAS associations, Mrs Sri as member of the association FOKUS.

D1 Is a code of research subjects with elementary education level and active in community economic activities. namely Ms. Supiah as a member of Sampoerna's CSR and Fisheries Office

D2 is a code of research subjects with a junior high school education level and is not active in community economic activities, namely Mrs. Masfiah.

\subsection{Understanding of Small Entrepreneurs Tipification A}

Smaller type A entrepreneurs, with the same level of education, are able to explain well their respective understanding of Islamic finance. Besides because they already know the theory, they have also directly experienced the experience of partnering with Islamic financial institutions. They have different opinions about halal and illegitimate interest of banks, but they both have less pleasant experiences in partnering with Islamic financial institutions. Islamic financial institutions are considered to be less proactive in marketing their products, and not utilizing the gold satrya program facilities which have the potential to attract many partners from MSME actors in Pasuruan district.

Personnel who are not trustworthy in management are one of the causes of disappointment in partnering with Islamic banks. Halal and illegitimate problems are believed differently by type A informants. Different beliefs make their backgrounds different in determining the choice of financing institutions as business partners. One party stated that bank interest is not unlawful, because conventional MUls and banks have been around for a long time and since a long time ago the MUI did not give illegitimate 
fatwas, so conventional banks remain an option. Other parties use paragraph references in the Al-Quran and believe that bank interest is haram, therefore business partners in the chosen financing are Islamic financial institutions, namely BPRS. Each of the conventional and sharia financial institutions that become business partners of Type A informants is very helpful in developing their business, and they are able to make financial statements well, so that the business progress of each period can be monitored properly

\subsection{Understanding Small Businessmen Tipification B}

Small businessmen typification B, never get information and are never interested in doing Islamic financing. This informant is more comfortable financing through CSR which he considers very much to provide: ease of financing procedures, business knowledge and insights, low cost, comparative study opportunities in various regions. From the experience of partnering with CSR, the informant concluded that to be able to cooperate with CSR one of the key attitudes and behaviors that must be held is honest and trustworthy. For him CSR reassures and nurtures. Informant B Typification knows and understands that bank interest is haram, but in everyday life he cannot avoid it, for him the need for funds can be resolved immediately, because of that he chooses pawnshops for urgent funding needs

\subsection{Understanding of C1 Typification Informants}

C1 typification informants, they all do not use financing from Islamic Financial Institutions, they on average use financing from CSR which is considered easy and cheap. For them the problem of illicit loan interest does not become a priority of thinking, for them it is better to use financing with interest but more beneficial and not detrimental to others than using non-interest financing but behaving in a business activity that is dishonest and even loses others. And for those who are important the problem of funding needs is resolved.

\subsection{Understanding of $\mathrm{C} 2$ typification informants}

In C2 typification informants, all had experience in partnering with Islamic financial institutions, only one in three informants felt dissatisfied and disappointed in partnering with LKS. The informant felt that HR in the field of marketing did not provide the 
correct information, and was wrong in calculating the amount of loans and installments, causing problems behind the day and this informant justified that additional loans or margins charged were no different from bank interest, which was felt unilaterally. and burdensome.

Two other informants, in fact really enjoyed, the ease, comfort and blessings of partnering with Islamic financial institutions in this case is BMT Maslahah. HR is trustworthy and full of family, the process is easy and fast, the margin given is not burdensome even though sometimes it is felt to be the same or a little more expensive than conventional banks, the ball picking system is very helpful and makes it easy for partners to pay in installments or save, the products offered are easy to understand by infoman, flexible and full of family in the face of disbursement of installment payments. Bank interest is recognized by them as haram, but for them it is not the problem that makes them make loans to Islamic banks, which is preferred because they are satisfied with the services of Maslaha BMT and the funding needs are met.

\subsection{Informants with D1 typification}

Financing is obtained from CSR which is considered easier, simpler and does not burden this because the interest is low and without collateral. Knowing the bank's illicit interest from ustads during Muslim prayer, but as long as it does not harm others, the results of their own sweat and not stealing, the bank's interest is not forbidden. Bu Supiyah's business is increasing as seen from the increasing number of orders.

\subsection{Informants with D2 typification}

Bu Masfiah's venture capital comes from its own capital, loans from SRB Jabal Tsur and BRI. Bu Masfiah was interested in choosing BPRS Jabal Tsur because the service picked up the ball, the procedure was easy, and the term profit sharing was used. while $\mathrm{BRI}$ is a business partner because it is considered cheap even though the procedure is not as easy as jabal sur. BRI only deals with loans because bu Amasfiah is committed not to enjoy the interest that it believes to be haram. Mrs. Masfiah acknowledged that interest was unlawful and should not be enjoyed, therefore financial transactions were mostly in BPRS Jabal Tsur, while BRI only borrowed, not to save because they did not want to enjoy interest. d) Bu Masfiah had no complete bookkeeping, but had begun to separate personal money from business money. Mrs. Masfiah said that her business 
was progressing, because from this business she could buy her children home, register for hajj, fulfill daily needs, pay off debts, and still be able to save.

Based on the results of the analysis per typification of small entrepreneurs, it can be explained that the understanding of small entrepreneurs towards Islamic finance is formed from the knowledge, beliefs and experiences they can and feel.

\section{Findings}

\subsection{Considerations for Selecting Financial Institutions}

The decision of each informant in determining the sources of financing, conventional or sharia in fact also varies according to what they understand, experience and feel. From the experience of the informants, it can be concluded that there are several considerations of small-scale entrepreneurs in choosing the following sources of financing:

a. Consideration of choosing a Sharia Financial Institution: 1) Convincing Jurisprudence and facts mentioned in the Koran that are interpreted in a linear manner, so that whatever the condition of this informant is consistently partnering with Islamic banks; 2) Convinced of the steadfastness of the heart that bank interest is haram, this informant is correct in understanding, but wrong in perceiving it, which according to him is halal if paying interest but is unlawful to receive interest, thus saving in Islamic banks and making loans to conventional banks; 3) Islamic financial institutions are chosen because of the various attractive facilities provided such as picking up the ball, contract financing system products, savings and loan procedures that are easy, flexible and full of family in dealing with bad loans.

b. Consideration of choosing Conventional Financial Institutions: 1) Assume banks are the same as other types of businesses that need income. Judging from the loan benefits, that borrowing at a bank for a halal business and not harming the other party would be better than borrowing non-interest but taking the rights of others and harming them. 2) Bank interest is considered not to be burdensome because there has been an agreement between the customer and the bank in front of the signatures of the loan contract, which means both parties enjoy each other: 3) Halal and unlawful bank interest is not a priority in determining the choice of a particular financial institution as a partner, because the problem is how is the need for funds fulfilled, the business stays on and halal; 4) Islamic banks have not been able to attract attention, because the services and services provided have not been able to compete with conventional financial institutions that are their business partners; 5) Borrowing in a conventional 
bank, the loan nominal can be obtained larger and the borrowing period is longer, so that it is not burdensome

\subsection{Understanding of Sharia Financing}

A person's understanding of Islamic financing, in addition to knowledge dependence, is also determined by the belief about the lawful or illegitimate interest of the bank. The results of the analysis of the understanding of the informants are grouped into two major parts of thought as follows:

Neo Revivalism; From the results of field research $18 \%$ have the same understanding but different perceptions, so it is different in its implementation. They understand that 1 ) Bank interest is usury and illegitimate, this informant consistently uses Islamic financing, despite the fact that he is disappointed with Islamic financial institutions that have been his business partners for years. 2) Bank interest is usury and illegitimate, with limited knowledge, informants assume that bank interest is unlawful if enjoyed, but not unlawful to pay, so that they save in Islamic financial institutions and make loans in conventional banks.

Modernism, That bank interest is allowed with various reasons and understanding as follows: 1) considers the bank to be the same as other types of businesses that need income, and interest is considered as bank income; 2) Interest on loans is considered not illegal, if the loan is for a halal business and does not harm others; 3) Halal and illegitimate bank interest are not a priority, the important is that capital needs are resolved, and banks provide facilities that are easy and convenient. 4) Signatures of agreement on loan and lending agreements are considered as the agreement of both parties to accept each other sincerely and no one feels disadvantaged.

\section{Discussion and Conclusion}

The need for strengthening faith education to direct the economy in accordance with what Islam wants. With faith the heart will always interact with God, automatically will love the truth, want goodness, hate evil. In order to ground or popularize the Islamic Economy in Pasuruan Regency, especially the financing problem which is the main requirement for every big or small businessman, then according to the findings described in the previous chapter, some things can be suggested as follows: 1) Require Islamic economic curriculum in the Diniyah Madrasa compulsory education program, to introduce Islamic economics from an early age, the aim is to instill religious values in students not only 
those related to the aqeedah and morality, but also include muamalah sharia content in the economic field. 2) Provide special space for the development of Islamic Economics in the Satrya Emas program. In this maslahat economic empowerment program, it is better not only to coordinate the Regional Organization (OPD) programs, but there is a special department that oversees all issues related to Islamic economics, such as zakat management, infaq, alms, endowments, as well as banking sharia. 3) The Pasuruan District MUI should make a policy to provide a curriculum for religious teachers or religious leaders to be able to deliver material about usury in their lectures, so that the lecture material is not only limited to aqeedah akhlaq but also the issue of sharia muamalah. 4) MUI DSN Pasuruan Regency, there should be regular coordination of each period, evaluating what is the operational problem of Islamic financial institutions in Pasuruan Regency. 5) Sharia Economic Community, which is a non-governmental organization for the development of Islamic economics in the Pasuruan regency area, should be supported by the local government, given appreciation and given space to be able to develop, because this community provides a tangible manifestation in overcoming unemployment, for example the Islamic sharia economic community, which every profit is taken a few percent to be infused, which then manifests a business bar for those who are still unemployed.

\section{References}

[1] Al-Quran dan Hadist

[2] ASLAN dan ELÇi, (2009), SME'S Rating System and Process in Turkey According to the Basel II Settlements, Eurasian Journal of Business and Economics 2009, 2 (4), 77-94. p. 93

[3] Astutik, (2016), Kabupaten Pasuruan Dalam Angka 2016, BPS Kabupaten Pasuruan, ISSN: 2355-4896

[4] Awan, Hayat M.; Khuram Shahzad Bukhari, (2011) "Customer's criteria for selecting an Islamic bank: evidence from Pakistan", Journal of Islamic Marketing, Vol. 2 Issue: 1, pp.14-27

[5] Bank Indonesia (2011), Kajian Akademik Pemeringkat Kredit Bagi Usaha Mikro, Kecil dan Menengah di Indonesia, BI, hal 23

[6] Bank Indonesia (2016), Publikasi Laporan Keuangan Bank Indonesia. Jakarta Indonesia

[7] Bitzenis, A. \& Nito, E. (2005), Obstacles to entrepreneurship in a transition business environment: the case of Albania, Journal of Small Business and Enterprise 
Development, Vol 12, No 4, 2005, pp 564-578

[8] Berger, Allen N. dan W. Scott Frame. (2005). "Small Business Credit Scoring and Credit Availability". Federal Reserve

[9] Choudhury MA, (2014), Is global financial and social stability possible?, International Journal of Islamic and Middle Eastern Finance and Management Vol. 7 No. 4, 2014 pp. 370-394 (c) Emerald Group Publishing Limited 1753-8394

[10] D Sanrego \& Ismail, (2014), Falsafah Ekonomi Islam, CV Karya Abadi, Jakarta

[11] David Irwin Jonathan M. Scott, (2010),"Barriers faced by SMEs in raising bank finance", International Journal of Entrepreneurial Behaviour \& Research, Vol. 16 Iss 3 pp. 245 $-259$

[12] Dewan Syari'ah Nasional, (2014), Pembiayaan Sindikasi (<em>al-Tamwil al-Mashrifi al-Mujamma'</em>), Majelis Ulama Indonesia, Jakarta

[13] Hamali and Abdullah, (2015), Determining Factors of Customers' Preferences: A Case of Deposit Products in Islamic Banking, Procedia - Social and Behavioral Sciences 224 (2016) 167 - 175

[14] Hadi, 2009, Makna keputusan Majelis Tarjih dan Tajdid Muhammadiyah Tentang Bunga Bank Bagi Pelaku Ekonomi Warga Muhammadiyah Surabaya

[15] Husserl, E. (2006), The Basic Problems of Phenomenology; From Lectures, Winter Semester, 1910-1911, The Netherlands; Springer, http://doi.org/10.1017/ CBO9781107415324.004

[16] Kamayanti, (2016), Metodologi Penelitian Kualitatif Akuntansi,Cetekan ke-2, Rumah Peneleh, ISBN: 978-602-74197-0-4, Surabaya

[17] Kuswarno, Engkus.,(2013), Fenomenologi, Widyapadjajaran, Bandung

[18] Moez Ltifi, Lubica Hikkerova, Boualem Aliouat, Jameleddine Gharbi, (2016) "The determinants of the choice of Islamic banks in Tunisia", International Journal of Bank Marketing, Vol. 34 Issue: 5, pp.710-730

[19] Riyadi at all, (2015), Indikator Kesejahteraan Rakyat 2015, Badan Pusat Statistik, Jakarta Indonesia

[20] Rivai, Harif-Amali. et al. (2007),

[21] Rehman S. \& Roomi MA., (2012), Gender and work-life balance: a phenomenological study of women entrepreneurs in Pakistan, Journal of Small Business and Enterprise Development, Vol. 19 No. 2, 2012 pp. 209-228, @ Emerald Group Publishing Limited

[22] Saad A. Metawa dan Mohammed Almossawi, 1998, Banking behavior of Islamic bank customers: perspectives and implications, International Journal of Bank Marketing 16/7 [1998] 299-313 ( ) MCB University Press [ISSN 0265-2323] 
[23] Sapuri, Rafy. (2008), Psikologi Islam, Rajawali Pers, Jakarta.

[24] Subhani at al, (2012), Consumer Creteria for the selection of an Islamic Bank,; eviden from pakistan. International Research Journal of Finance and Economics (IRJFE) No. 94

[25] Salman Syed Ali dan Hamid Hasan, (2014), Development Index, Islamic Researach and Training Institute, Member of The Islamic Development Bank Group. page 7-9

[26] Wartoyo (2010) BUNGA BANK: ABDULLAH SAEED VS YUSUF QARADHAWI (Sebuah Dialektika Pemikiran antara Kaum Modernis dengan Neo-Revivalis), La_Riba Jurnal Ekonomi Islam, Volume IV, No. 1 